\title{
Radical Reduction of Aircraft Fuel Consumption by Optimizing Aerofoil by New Evolutionary Algorithms
}

Jan Müller

\author{
Brno University of Technology \\ Institute of Automation and Computer Science \\ Technická 2896/2, 61669 Brno \\ Czech Republic \\ xmulle11@vutbr.cz
}

\begin{abstract}
This work deals with aerofoil aerodynamic features optimization, not only to improve flight features, but also to improve economy, ecology and safety of parameters of flight technique.

In cruise mission, occupying the most flight time, the most important parameter is aerodynamic drag, which directly influences the aeroplane operational economy of transportation. Drag reduction is adequately reflected in the fuel consumption reduction. Consumption reduction is also adequately reflected in the flight ecology. In take-off and landing mission, the safety is priority and directly influences the aerofoil geometry.

For cruise mission the new modified evolutionary algorithms (EA) are used to parameters incoming to Bezier-PARSEC 3434 parametrization. Such aerofoil is processed and evaluated by the Xfoil program. The change of model parameters results to optimal aerofoil shape.

The DCAG (Direct Control Aerofoil Geometry) is unique developed mechanical device, makes possible the change of curvature of aerofoil, and also aerofoil geometry. DCAG is based on the rotary principle, which makes it possible to define the curvature of aerofoil for every roll as well as defining the geometry in the variable parts of aerofoil.

For take-off and landing mission the best combination of slots and flaps is choosed. To improve of laminarity and reduce turbulent flow the DCAG is used.

The work results to optimization, which is 50 times faster in comparison to ordinary optimization, with minimum of input parameters (flight speed, chord length, range of angles of attack and fitness function).

The optimized aerofoil can achieve savings in fuel consumption up to $44 \%$ in comparison with unoptimized aerofoil, the aerodynamic drag reduction up to $44 \%$.

The output was checked by ANSYS Fluent simulation.
\end{abstract}

\section{Keywords}

Evolutionary algorithms, shape of aerofoil, optimization of shape, Bezier-PARSEC model. 


\section{Introduction}

Optimal design of aircraft technology is a multidisciplinary problem. Aerodynamics, design, acoustics, manufacturing and economics are some of the disciplines involved in this type of problem. Solutions of only one of these disciplines may lead to conflicting requirements (e.g. optimization of lift and drag against strength and weight requirements).

EA methods are based on the population, simulating the development of species and survival of the strongest and compared with traditional optimization techniques have following advantages:

- robustness: In practice, they produce faster convergence to optimal solutions. In addition, they can manage differentiated fitness functions.

- simplicity: EA uses only function values for each candidate design. They do not require substantial modifications or complex interfaces for use.

In our case, for solving of aerofoil aerodynamics was used numerical optimization of EA, with results tested by Computational Fluid Dynamics (CFD). This optimization of aerodynamic aerofoil features is followed by control of its geometry according to patent [1]. This is a completely new design solution with the following advantages:

- reducing of aerodynamic drag. As a result, fuel consumption is reduced as a result of reduced airplane power requirements.

- improving of aerodynamic lift to values unreachable by present technologies. As a result, this means a radical reduction in the need of take-off and landing runway length. Reducing the landing speed results in higher airplane safety.

- increasing of the manoeuvrability of the airplane using possible various of aerofoil shapes along the whole span of wing

- DCAG is also useable for other types of transport such as boats, ships, submarines, etc.

\section{Present state}

Nowadays to improve the aerodynamic features various mechanisms are used. But such mechanisms split the aerofoil into more segments, which results to discontinuation of laminar flow. Various attempts have already been made to develop aerofoil as one segment, but only mechanically complicated solutions were developed.

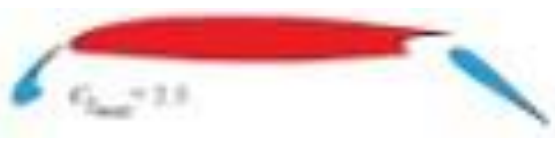

Figure 1: Turbulent flow

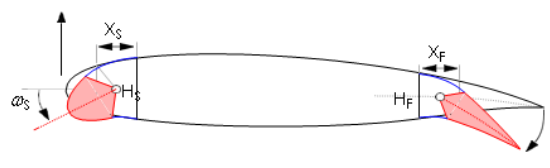

Figure 2: Laminar flow 
In general, there is an effort to develop an aircraft with one segment aerofoil for all flight missions and with slots and flaps used. One segment aerofoil supports laminar flow, which positively influences aerofoil aerodynamic features. It reflects to economy, ecology and flight safety improvement. An example is the AFTI / F-111 fighter.

\section{Project AFTI/F-111}

By the end of the 1960s, the first tests were made when NASA worked to evaluate the problems of the first F-111A for the Air Force and Navy [2]. In the 1980s, the supercritical wing was replaced by the Boeing MAW wing. The concept is based on US Patent No. US 4,335,502 (1982) in Figure 4.

The result was increase of range by $25 \%$, improvement of lift/drag ratio by $20 \%$. Despite these good results, the fighter were not produced, because of constructional complexity.

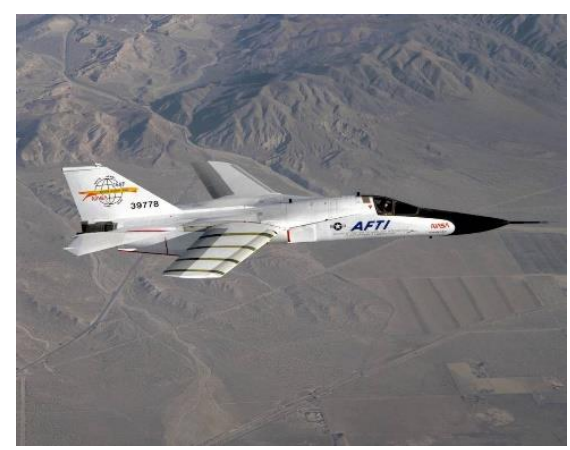

Figure 3: Fighter AFTI/F-111

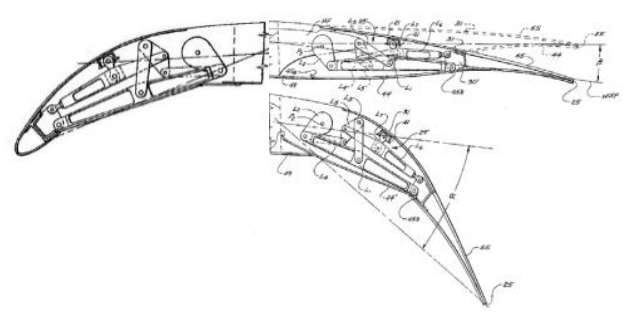

Figure 4: Patent US 4351502/1982

In addition to the one segment aerofoil, the aerofoil shape is also reflected in the aerofoil aerodynamic features. The optimization is used to find aerofoil with best aerodynamic features. Such optimization helps to find the optimal solution, therefore optimal aerofoil shape. An example is the ATR-42-4 aeroplane. 


\section{Project ATR-42-4}

An example of aerofoil shape change is ATR-42-4 [3], [4], [5]. [6], when the aerofoil shape modification is realized by the morphing of the upper side of the aerofoil, as shown in (see Figure 5, 6).

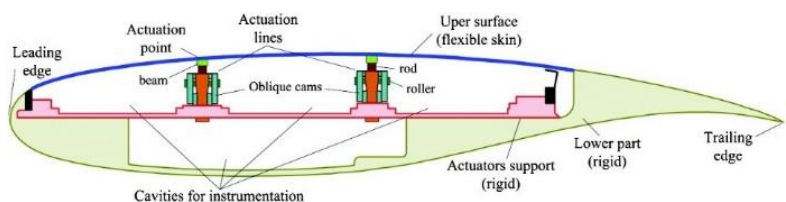

Figure 5: Aerofoil morphing mechanism ATR-42-4

The genetic algorithms are used for aerofoil shape optimization. Every individual in population is defined by two real values, representing the stroke of the actuators. This stroke values are between original aerofoil and morphed aerofoil. The fitness function was defined to calculate individuals in population and to reach aerofoil drag minimization.

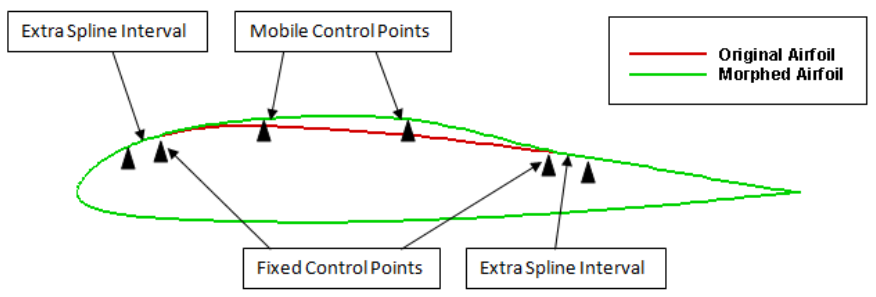

Figure 6: Aerofoil morphing results ATR-42-4

Approximation of the upper deformed part is realized by cubic spline. The aerofoil features are represented by the Reynolds number and the angles of attack, which are converted into a batch file. The aerofoil coordinates ( $x, y$ values) must be available for the Xfoil program, which calculates the aerofoil lift and drag values.

Drag decreasing of up to $26.73 \%$ was reached by such aerofoil geometry optimization. Also drag decreasing results to a reduction in fuel consumption of more than $20 \%$. The lift also increased significantly, especially in the range of small, positive and negative lead angles. 


\section{Parameterization for Cruise Mission}

The aerofoil aerodynamic shapes are represented by individual coordinates. But when optimizing and working with many aerofoils, it is necessary to represent the aerofoil shapes by several parameters. The aerofoils representation using only a few parameters is called parameterization. The advantage of parameterization is aerofoil characterization by several parameters in comparison with coordinates counting most often several hundred values.

\section{Bezier-PARSEC 3434 Parametrization Optimization}

This method is combination of parametrization Bezier and PARSEC techniques. By such combination the Bezier-PARSEC method gains advantages provided by both mentioned parametrization techniques [7], [8], [9].

The Bezier-PARSEC 3434 parameters are use for optimization application. The model needs 6 parameters for aerofoil thickness and 8 parameters for aerofoil camber. The BP3434 parameters crossover, mute and randomly change. The thickness and camber from Bezier-PARSEC make the shape of aerofoil, which is normalized to $\mathrm{x}, \mathrm{y}$ coordinates.

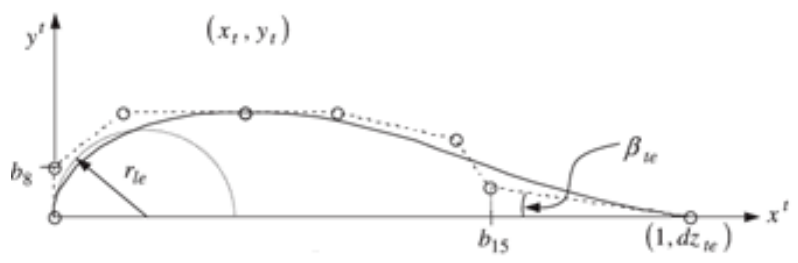

Figure 7: Bezier-PARSEC 3434 thickness

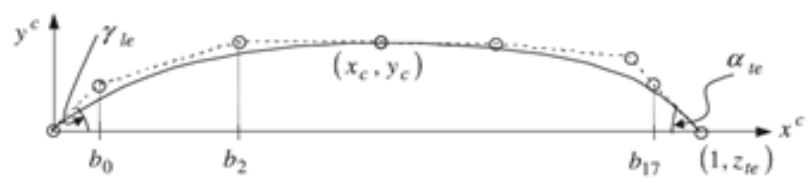

Figure 8: Bezier-PARSEC 3434 camber 


\section{New Modified Evolution Algorithms for Cruise Mission}

The difference in aerofoil aerodynamic features optimization is in obtaining of aerofoil. While cruise mission gains aerofoil from Bezier-PARSEC 3434 parametrization optimization, the landing obtains aerofoil from a combination of depth, slot angles and depth, flap angles. For take-off no optimization is used [10].

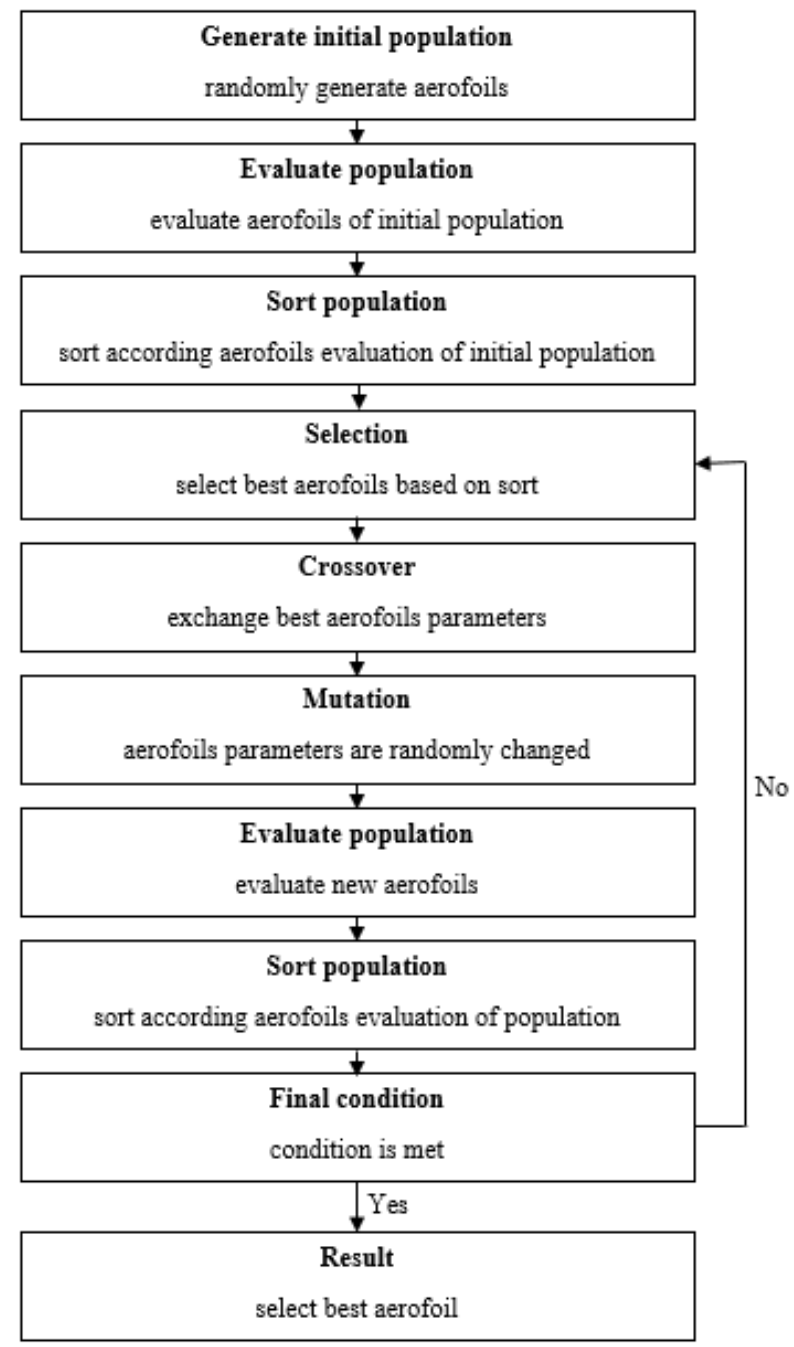

Figure 9: Evolution algorithm operators 
Crossing combines the parameters of the best aerofoils, which means the best evaluated. The aerofoil shape is subjected to the Xfoil calculation program. The result is a new population of aerofoils.

The theoretical proof of the crossover correctness is based on theory of schemes (building block hypothesis). It assumes that combination of best parents (aerofoils) creates new children (aerofoils) better than parents (aerofoils). The highest qualities of parents (aerofoils) alive in their children (aerofoils).

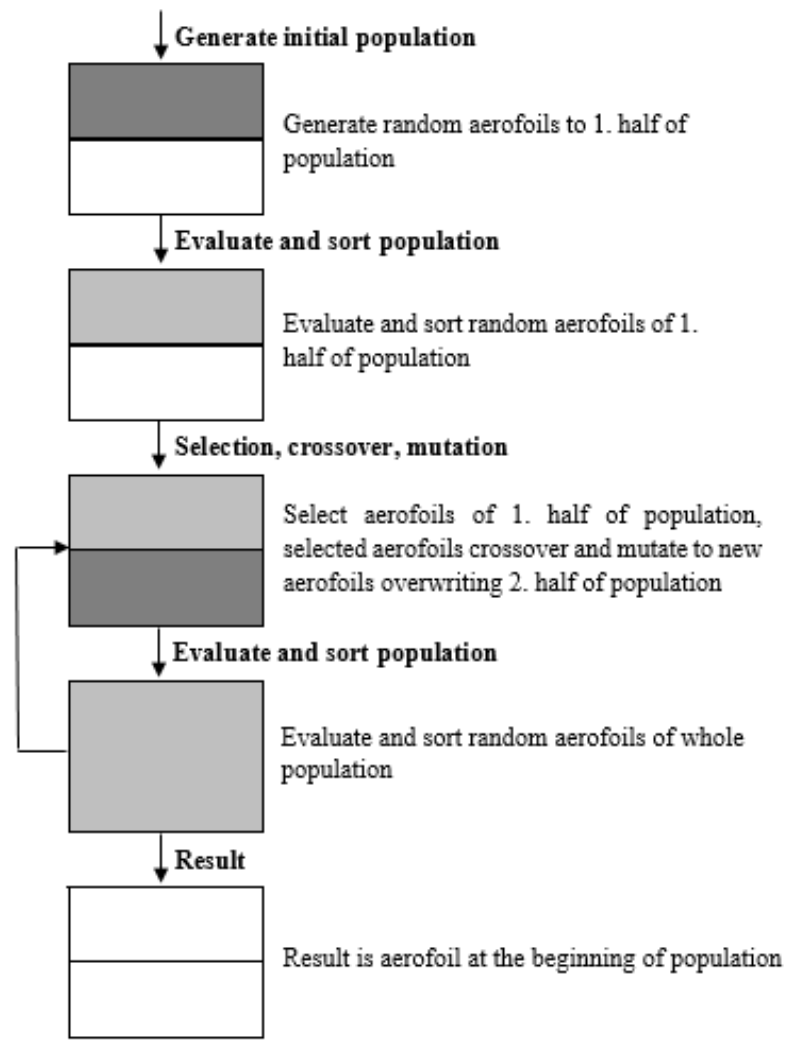

Figure 10: Evolution algorithm population

The most important is the part where the optimization crossover and mutates the aerofoils from the first part, while the second part is overwritten by the newly created aerofoils. 


\section{Optimization of Cruise Mission}

For cruise mission is most important aerodynamic feature aerofoil drag having direct relation to fuel consumption. First the parameters are passed to Bezier-PARSEC parameterization. Bezier-PARSEC parameterization is combination of parameterization technique PARSEC and Bezier curves. The result of parameterization is aerofoil thickness and camber, from which the aerofoil shape is calculated.

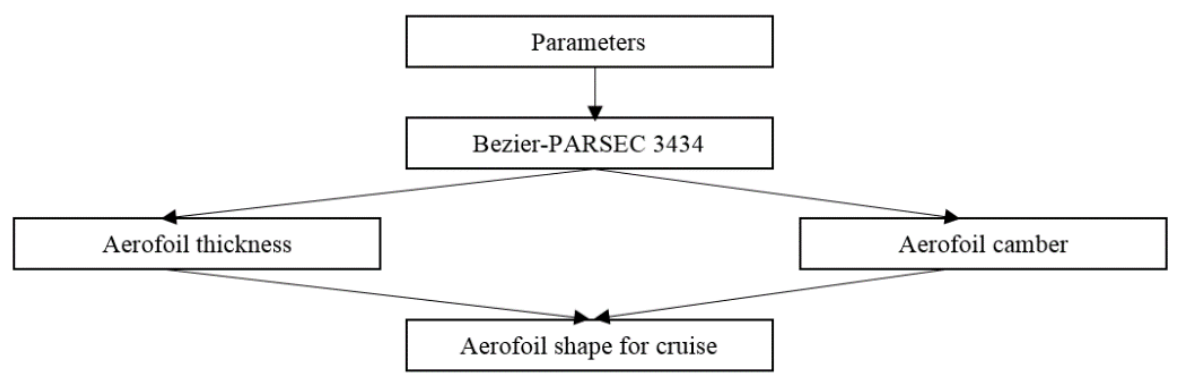

Figure 11: Shape generation

Once parameterization is passed, the Reynolds number and the angle of attack are added. Such data are inserted into program Xfoil, which uses panel methods to calculate fundamental aerodynamic parameters of aerofoil during cruise mission.

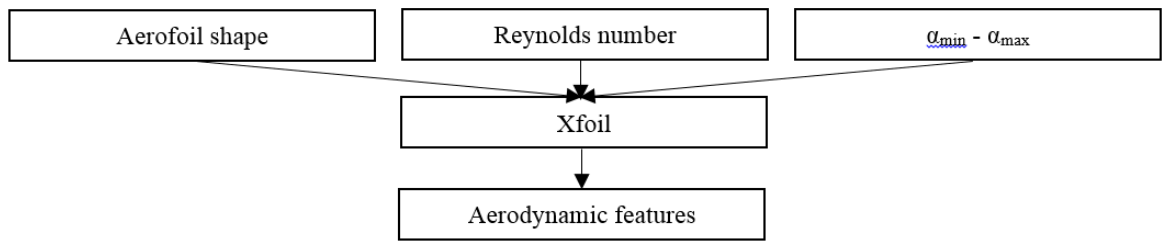

Figure 12: Obtaining aerodynamic features

Every mission has specific requirements to aerodynamic features. The optimization for landing and take-off will be mentioned in following paragraph. 


\section{Optimization of Landing Mission}

To perform landing optimization is necessary to define depth, angle of slots and flaps and shape of aerofoil for cruise mission. The resulting shape for landing consists of depth, angle of slots and flaps and shape of aerofoil for cruise mission.

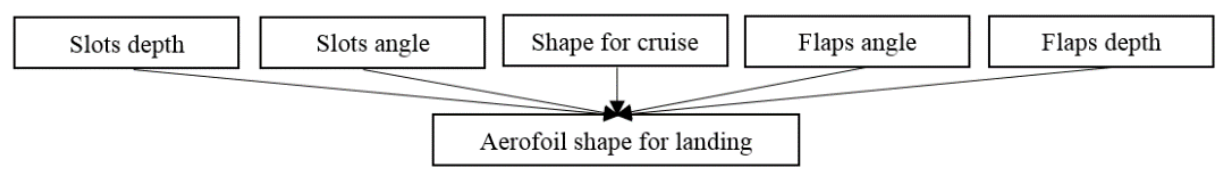

Figure 13: Obtaining aerofoil shape for landing

Calculation of aerodynamic features for landing is via Xfoil and is same (see Figure 12).

\section{Calculation of Take-off Mission}

The take-off aerofoil consists of the shape of cruise and the depth, angle of the landing flaps. No optimization is need.

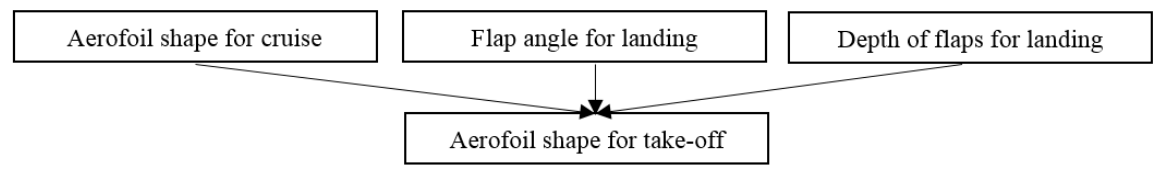

Figure 14: Obtaining aerofoil shape for take-off

Calculation of aerodynamic features for take-off is via Xfoil and is same (see Figure 12). 


\section{Direct Control Aerofoil Geometry (DCAG)}

The DCAG developed mechanical device, makes possible the change of curvature of aerofoil, and also aerofoil geometry, all very simple (the principle is illustrated in Figure 4). DCAG is based on the rotary principle, which makes it possible to define the curvature of aerofoil for every roll as well as defining the geometry in the variable parts of aerofoil.

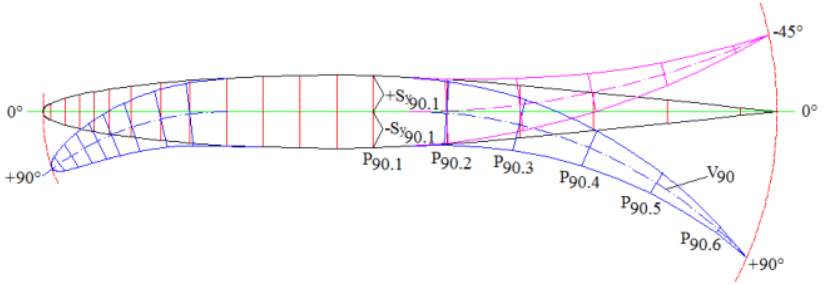

Figure 15: Expected geometry of aerofoil

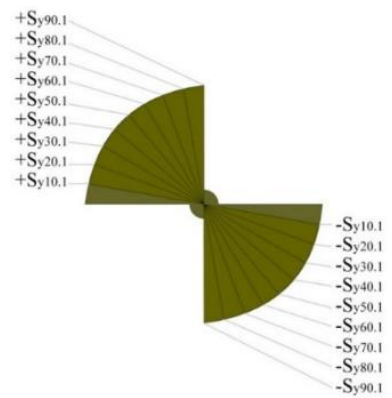

Figure 16: Transverse section $\mathrm{P}_{1}$

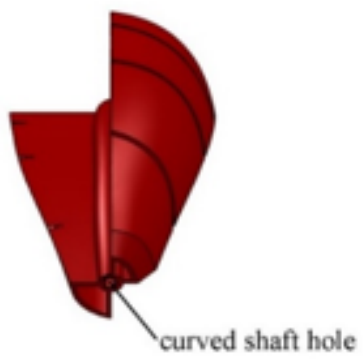

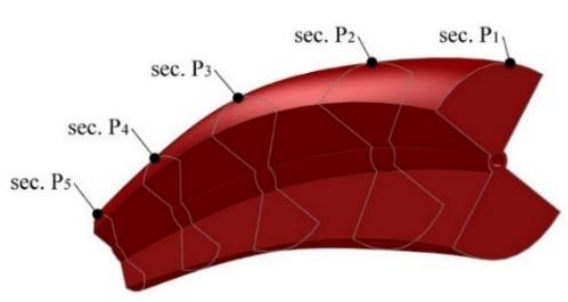

Figure 17: Retainer surface

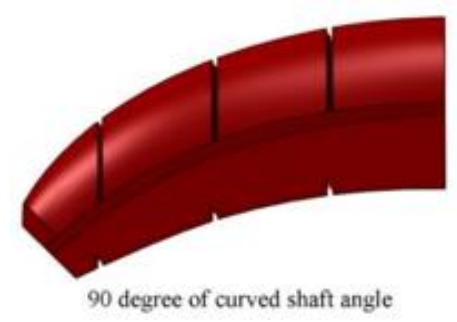

Figure 18: Revolution retainer 


\section{detail "A" of skin slot}

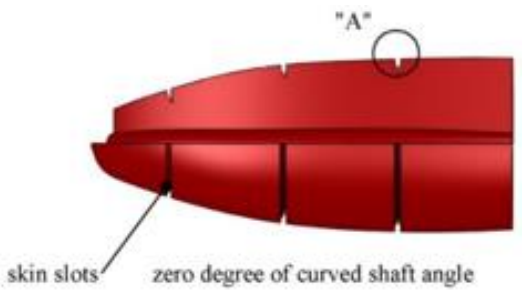

Figure 19: Revolution retainer
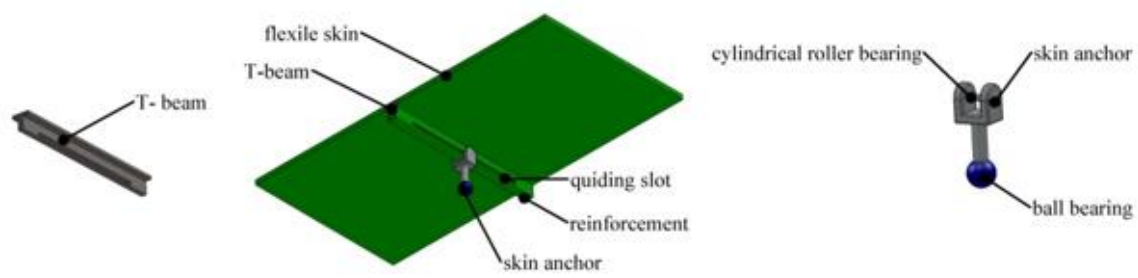

Figure 20: Skin
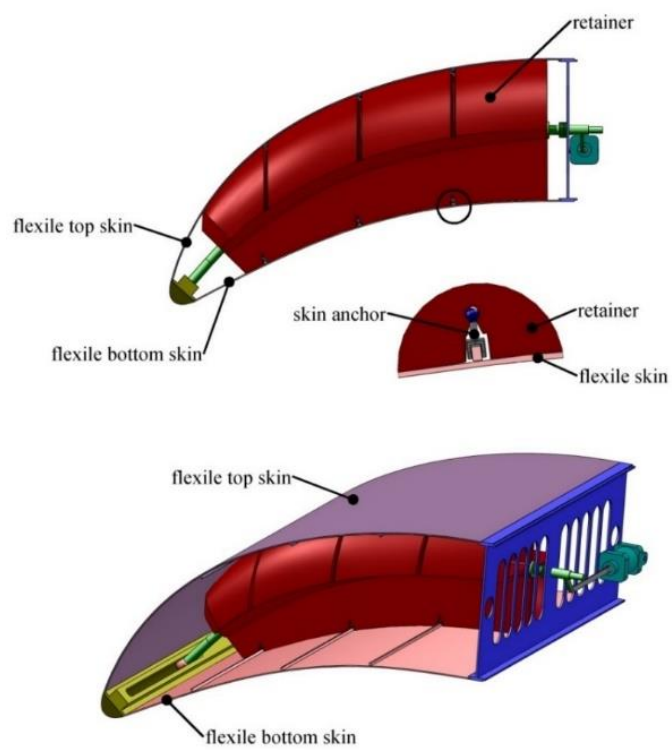

Figure 21: Device with skin 


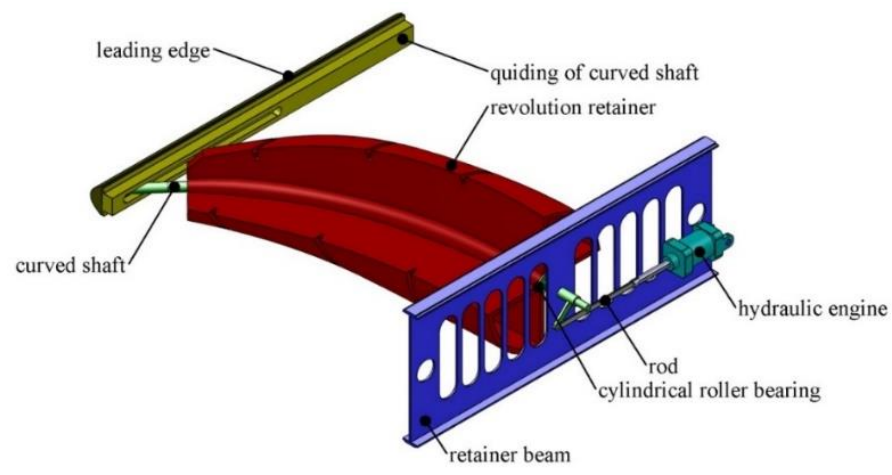

Figure 22: Final device assembly without skin

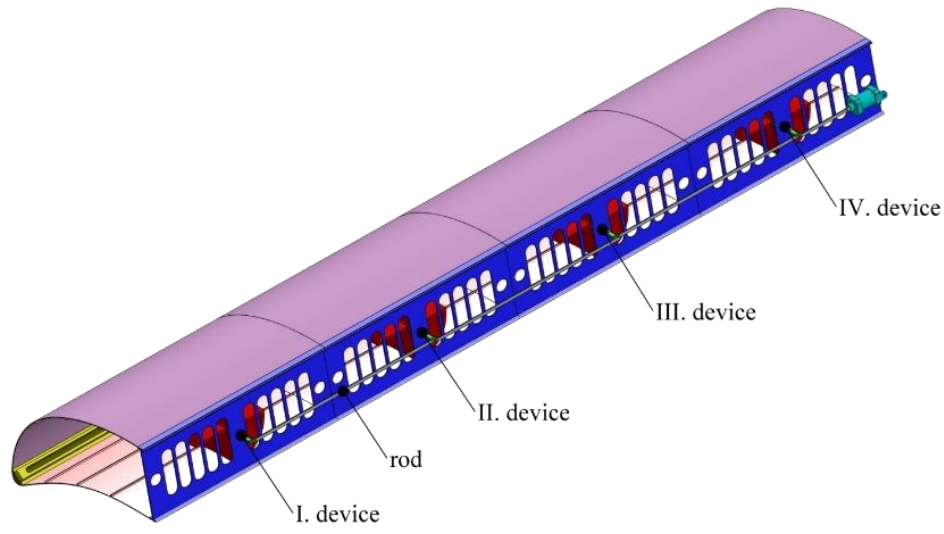

Figure 23: Resulting wing

\section{Application}

This device is suitable for many applications. The application for wings can reach optimal aerodynamic features for every flight mission, increasing of lift resulting to STOL effect, higher manoeuvrability of aircraft, direct de-icing by skin micro rotations.

Also the device can be used for changing of wind turbines blade shapes, changing of water turbines blade shapes, for example, for the Francis and Kaplan turbines. Usage of device for turbines could increase efficiency.

A quite different application is formula one racing cars. It would be possible to apply DCAG both the front and the rear wing to reach better accuracy and effective pressure regulation.

These application examples are not an full list of all possible applications, but only a small example. 


\section{Aerofoil Aerodynamic Features Calculation for the Fitness Function}

Airfoils are designed either by the inverse method or by a combination of direct and inverse method [11], [12], [13] at present. A panel method is often used for the inverse method, e.g. Xfoil by Mark Drely, but profiles are still being designed using the conformal transformation method from Richard Eppler, Franz Xaver Wortmann. The inverse methods used to solve the profiles by the panel method, but more complex methods can be used, e.g. finite volume method or finite element method such as ANSYS Fluent.

\section{Program XFoil}

XFoil combines compressibility correction with methods associated with viscous and non-viscous flows [10]. XFoil uses two basic equations, boundary layer retention and panel method. Accuracy can be improved by eg Euler or Navier-Stokes equations, but it would slow down the calculation [14], [15].

Since 1970, aerodynamics has been very often used as a panel method, solving the potential flow in any general part of the profile by a model based on discretization of the profile contour using singularly connected straight panels with linear vortex distribution between the end points, as shown in Figure 24. [16], [17], [18], [19].

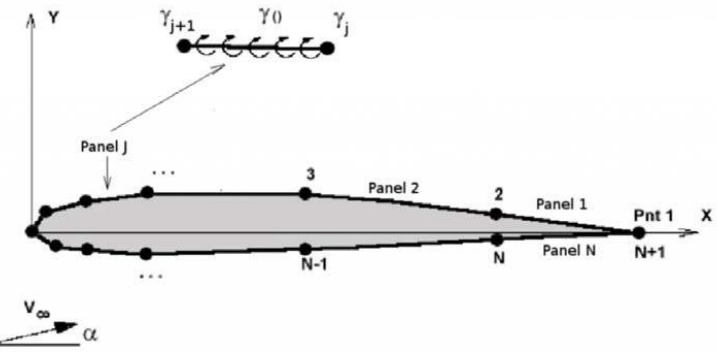

Figure 24: Potential aerofoil flow solution (panel method)

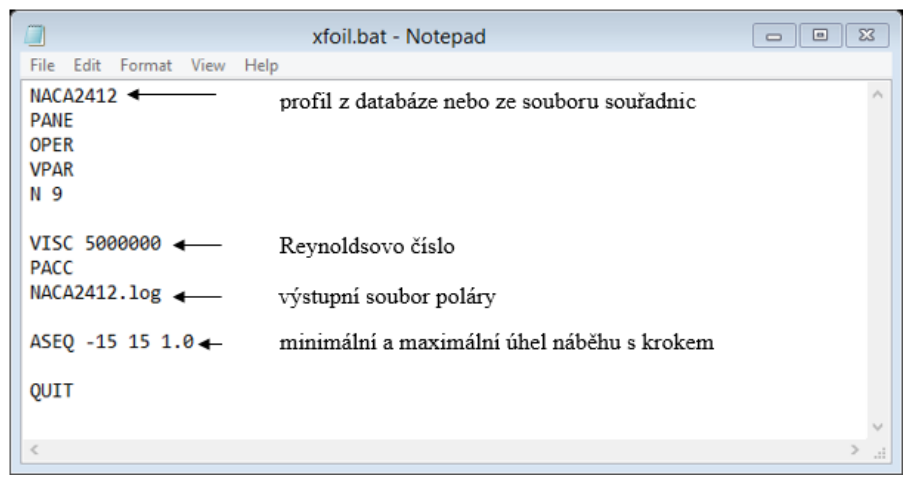

Figure 25: Sample bat file 
XFoil can be run from the command line and interactively controlled through commands and functions offered by menus, or bat file can be created and sent to the program, see Figure 25.

Results of XFoil program calculation are lift, drag and moment coefficients for angles of attack range.

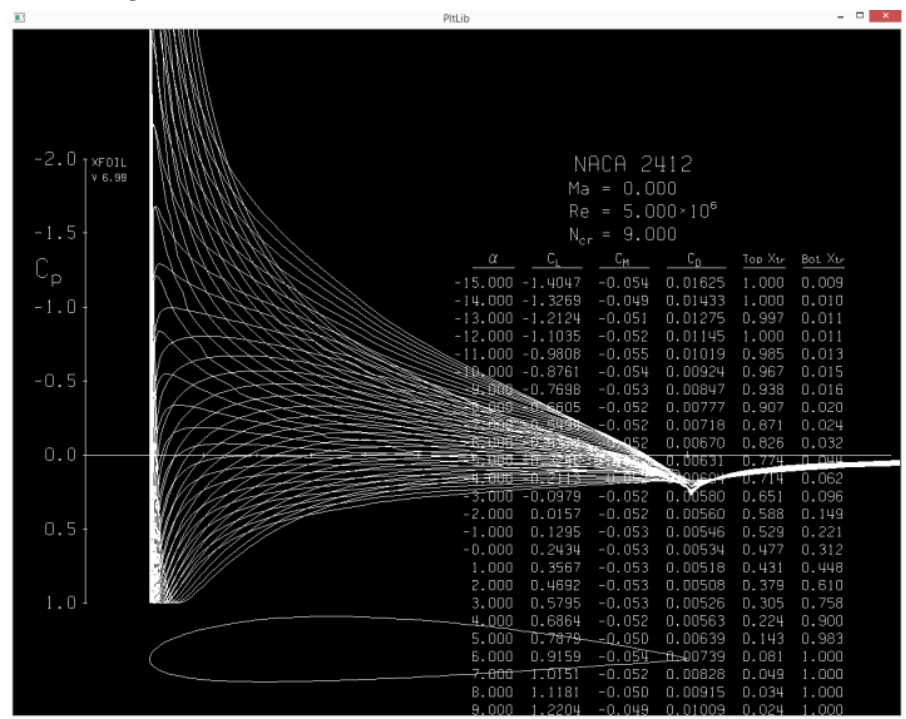

Figure 26: Lift, drag and moment coefficients in program Xfoil.

\section{Program ANSYS Fluent}

ANSYS Fluent is a complex program used for computational fluid dynamics (CFD), especially for simulations solving fluid flow problems.

Physical models and their combinations in ANSYS Fluent, unlike Xfoil, are able to solve almost all problems in industry [20]:

- aviation - airplanes, examples of air flow around wings, spaceships

- land transport - improve car aerodynamics

- medicine - blood flow in artificial heart, air flow during breathing

- chemical engineering - flow through pumps or tubes, combustion of coal in furnaces

- energy engineering - increasing turbine efficiency, development of wind power plants

Multi-physical simulation allows to transmit the results of one simulation as input data to another simulation.

Today, ANSYS Fluent is the most widely used CFD simulation software. 


\section{Results}

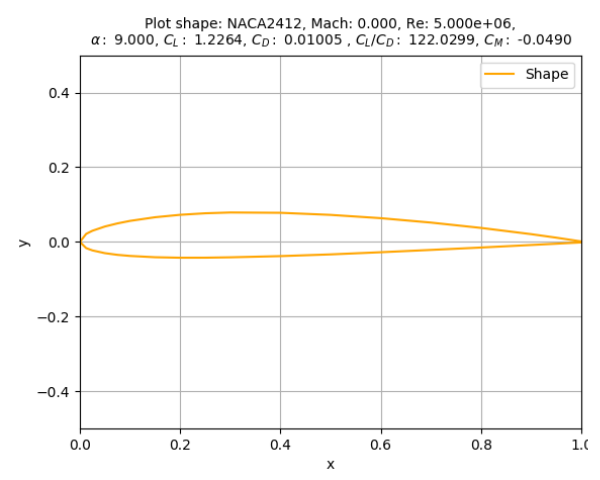

Figure 27: NACA 2412 aerofoil shape

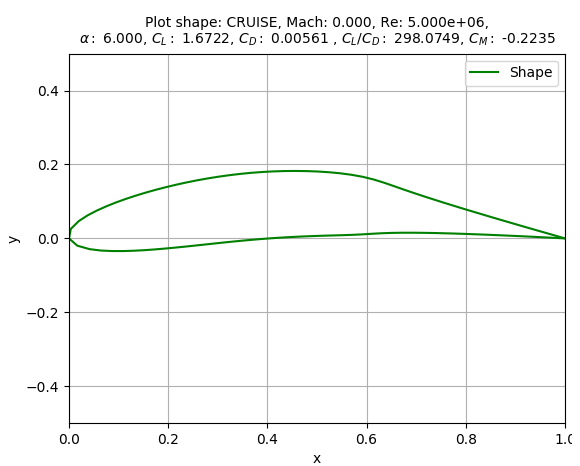

Figure 28: Optimized aerofoil shape

The comparison of the NACA 2412 aerofoil shape [21] [22] (Cessna 172) and optimized aerofoil shape shows obvious differences between the shapes of the aerofoils (see Figure 27 and 28), which are reflected in different aerodynamic characteristics and features.

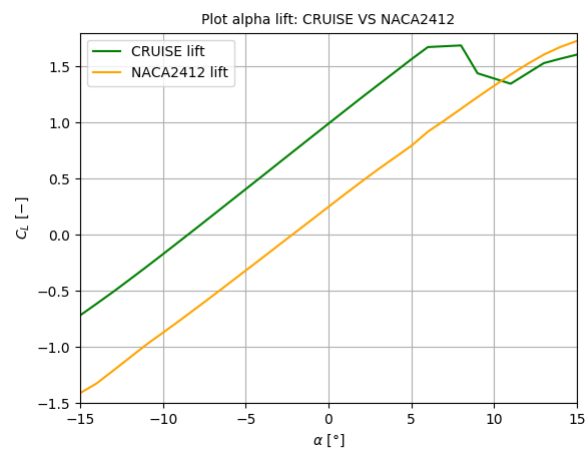

Figure 29: Aerofoils lift curves

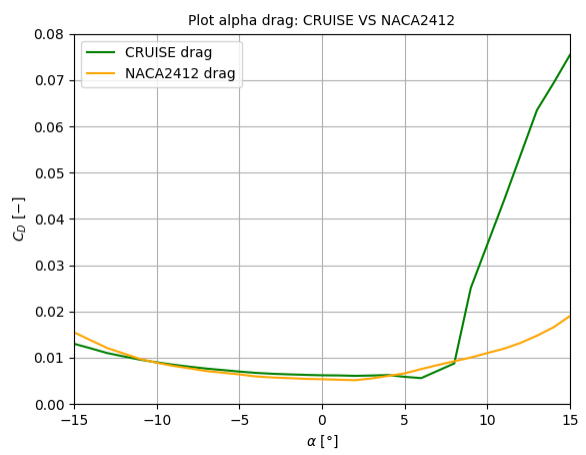

Figure 30: Aerofoils drag curves

From Figures 29 and 30 is shown higher lift and lower drag of the optimized aerofoil during cruise flight mission. 


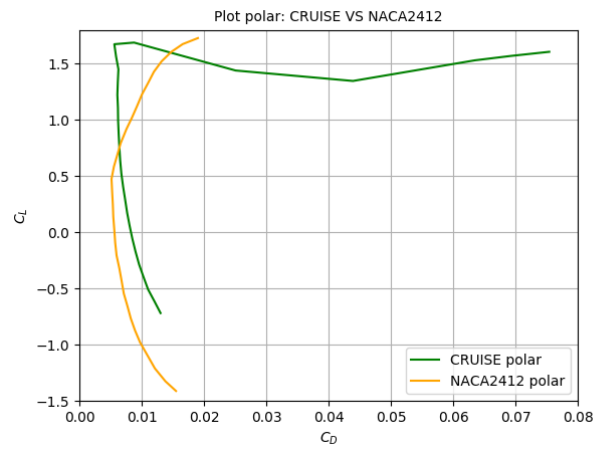

Figure 31: Aerofoil polars

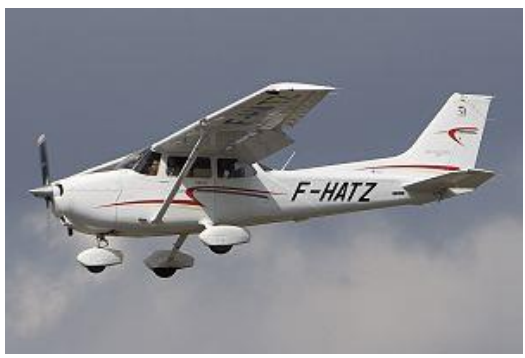

Figure 32: Cessna 172

To check the results of the aerofoil optimization based on Xfoil the simulation with same aerodynamic conditions was done in ANSYS Fluent. The differences between Xfoil (based on panel model) and ANSYS Fluent (transition k-kl-omega model) results were in few percent (max. $4.43 \%$ ).
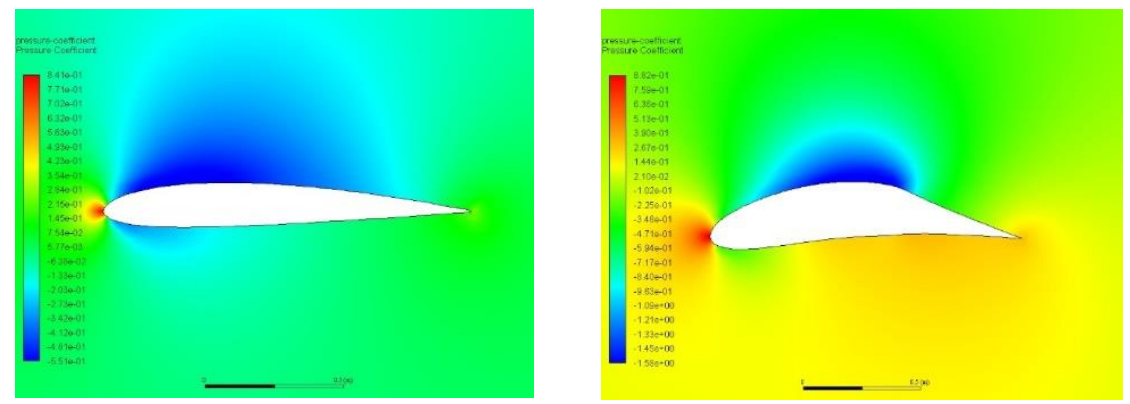

Figure 33: Pressure coefficients in ANSYS Fluent for angle of attack $\alpha=0^{\circ}$

\begin{tabular}{|l|r|r|r|}
\cline { 2 - 4 } \multicolumn{1}{c|}{} & Optimized Aerofoil & NACA 2412 Aerofoil & Improvement [\%] \\
\hline$\alpha\left[^{\circ}\right]$ & 6.000 & 9.000 & - \\
\hline$C_{L}[-]$ & 1.67220 & 1.22640 & $\mathbf{3 6 . 3 5 0 2 9}$ \\
\hline$C_{D}[-]$ & 0.00561 & 0.01005 & $\mathbf{4 4 . 1 7 9 1 0}$ \\
\hline$C_{L} / C_{D}[-]$ & 298.07487 & 122.02985 & $\mathbf{1 4 4 . 2 6 3 8 9}$ \\
\hline
\end{tabular}

Table 1: Improvement of aerodynamic parameters of optimal and NACA 2412 aerofoil 


\section{Improvements}

New modified evolution algorithms are used with aerofoil parametrical model (Bezier-PARSEC 3434) to create a new aerofoil shape based on the parameter values generated by these new evolutionary algorithms. The aerodynamic parameters calculated by XFoil are then evaluated using the fitness function.

This new methodology of aerofoil shape calculation and created software achieved:

- initial optimization conditions does not need the template, they are completely general

- calculations quickly converge to the result (according to the set fitness function), compared to currently used calculations

- optimized aerofoil calculations are fast, compared to currently used calculations

- optimized aerofoil shapes have a very low aerodynamic drag during cruise mission

- the optimized aerofoil achieved savings in fuel consumption up to $44 \%$

- environmental impact was reduced up to $44 \%$

- the operational costs were reduced up to $44 \%$ 


\section{Conclusion}

The developed modified evolutionary algorithms introduce new inventions to aerofoil optimization:

- conventional optimization starts by selection of existing aerofoil to be optimized and such selection is based on aerodynamics experience, but new modified evolutionary algorithms is based on a randomly generated first parent population, creating an independent and optimal configuration for optimization without need for any templates.

- Bezier-PARSEC 3434 aerofoil geometry model was used for optimization. With it, the aerofoil can be parameterized for optimal profile shape.

- calculations quickly converge to the result (according to the set fitness function), compared to currently used calculations

- $\quad$ optimized aerofoil shapes have a very low aerodynamic drag during cruise mission

- the optimized aerofoil achieved savings in fuel consumption up to $44 \%$, what is reflected to reducing of pollution up to $44 \%$, and is reflected reduction of operational costs up to $44 \%$

- where based on aerodynamics experience, an existing profile is selected and optimized, a new profile optimization is created based on a randomly generated first parent population, creating an independent and optimal configuration for optimization without any templates

Bezier-PARSEC 3434 parameterization, XFoil program for calculation and new modified evolutionary optimization algorithms have not been applied yet. The industrial application of the created software and the invention is very wide and in the case of aircraft technology brings the following basic advantages:

- reduction of aerofoil aerodynamic drag based on calculation. As a result, fuel consumption is significantly reduced

- improvement of aerodynamic characteristics of the wing for different flight missions resulting from the calculation

- increasing of wing lift to values unreachable by known means based on calculation. As a result, this means a need of shorter runway length for takeoff and landing (STOL characteristics). Reducing the airplane's landing speed results in better airplane safety and lower operating costs

The work results to optimization, which is $\mathbf{5 0}$ times faster in comparison to ordinary optimization, with minimum of input parameters (flight speed, chord length, range of angles of attack and fitness function).

The optimized aerofoil can achieve savings in fuel consumption up to $44 \%$ in comparison with NACA 2412 aerofoil (Cessna 172), the aerodynamic drag reduction up to $44 \%$. The operational costs are reduced up to $44 \%$.

The work was integrated into programmed software (approx. 4500 lines of source code in Python). 


\section{References}

[1] Zařizení pro kontinuální a definovanou změnu geometrie tvaru a zakřivení profilu kř́del. b.r. Česká republika. Patent 300 728. Uděleno 29.7.2009.

[2] F-111 Advanced Fighter Technology Integration [online]. USA: NASA, 2017 [cit. 2019-06-30]. Dostupné $\mathrm{z:}$ https://www.nasa.gov/centers/dryden/multimedia/imagegallery/F111AFTI/EC85-33205-07.html

[3] GABOR, Oliviu, Andreea KOREANSCHI a Ruxandra BOTEZ. Low-speed aerodynamic characteristics improvement of ATR 42 airfoil using a morphing wing approach. Department of Automated Production Engineering École de Technologie Supérieure. Montréal, Canada, 2012.

[4] KROO, Ilan. NONPLANAR WING CONCEPTS FOR INCREASED AIRCRAFT EFFICIENCY. VKI lecture series on Innovative Configurations and Advanced Concepts for Future Civil Aircraft. USA, 2005.

[5] HINSHAW, Tyler. Analysis and Design of a Morphing Wing Tip using Multicellular Flexible Matrix Composite Adaptive Skins. Virginia Polytechnic Institute and State University. Virginia, USA, 2009.

[6] PANKONIEN, Alexander. Smart Material Wing Morphing for Unmanned Aerial Vehicles. University of Michigan. Michigan, USA, 2015.

[7] SALUNKE, Nilesh, Juned AHAMAD a S.A. CHANNIWALA. Airfoil Parameterization Techniques: A Review. American Journal of Mechanical Engineering. USA, 2014.

[8] Profily nosných a ocasnich ploch, listů vrtulí a rotorů [online]. Praha, Česká republika: e-magazín Akademie letectví, 2008 [cit. 2019-06-30]. Dostupné z: http://www.airspace.cz/akademie/rocnik/2008/07/profily.php

[9] LI, Wu a Sharon PADULA. Performance Trades Study for Robust Airfoil Shape Optimization. AIAA Journal. Reston, USA, 2003.

[10] KŘÍŽÁK, Michal. INTEGRACE VÝPOČTOVÉHO PROGRAMU XFOIL V PROSTŘEDNÍ MATLAB. VUT v Brně. Brno, ČR, 2010.

[11] ABBOTT, IRA a ALBERT DOENHOFF. THEORY OF WING SECTIONS. DOVER PUBLICATIONS, INC. NEW YORK, USA: DOVER PUBLICATIONS, 1958. ISBN 0-486-60586-8.

[12] ROSKAM, Jan. Airplane Design. DARcorporation. USA, 2003.

[13] RŮŽIČKA, Pavel. Vývoj profilů kř́del lehkých letounů pro nizká Reynoldsova čisla s nižší citlivostí na výrobni nepresnosti. VUT v Brně. Brno, ČR, 2001. 
[14] MASTERS, D., N. TAYLOR, T. RENDALL, C. ALLEN a D. POOLE. Review of Aerofoil Parameterisation Methods for Aerodynamic Shape Optimisation. AIAA Journal. Reston, USA, 2015.

[15] POONSONG, Prasobchok. DESIGN AND ANALYSIS OF A MULTI-SECTION VARIABLE CAMBER WING. University of Maryland. Maryland, USA, 2006.

[16] ENTZ, R., L. CORREA, R. OLIVEIRA, F. CATALANO a M. MEDEIROS. Methods for Preliminary Airfoil Optimization. AIAA Journal. Reston, USA, 2009.

[17] CHIGULURI, Bhanu. Multi-point Optimization of Airfoils. GEORGIA INSTITUTE OF TECHNOLOGY. Georgia, USA, 2011.

[18] JAMESON, Antony. Aerodynamic Shape Optimization Using the Adjoint Method. Lectures at the Von Karman Institute. Brussels, Belgium, 2003.

[19] LANE, Kevin a David MARSHALL. Inverse Airfoil Design Utilizing CST Parameterization. 48th AIAA Aerospace Sciences Meeting Including the New Horizons Forum and Aerospace Exposition. Orlando, Florida, USA, 2010.

[20] VRBA, Pavel. Řešení proudění v pokusném kanálu pomocí CFD. Západočeská univerzita v Plzni. Plzeň, ČR, 2016.

[21] ABBOTT, Ira H. Theory of Wing Secrion. New York: United States of America Dover Publications, Inc., 1958.

[22] MATSSON, Dr. Aerodynamic Performance of the NACA 2412 Airfoil at Low Reynolds Number. Tulsa: Oral Roberts University, 2016. 


\section{Publications}

MULLER, Jan. Radical Reduction of Aircraft Fuel Consumption by Optimizing Aerofoil by New Evolutionary Algorithms. Hindawi Publishing Corporation

MULLER, Jan. Improving wing geometry, Part I.: Mechanical design. International Conference on Soft Computing MENDEL. Brno, ČR, 2018.

MULLER, Jan a Pavel OSMERA. IMPROVING AEROFOIL GEOMETRY PART II.: OPTIMALIZATION. International Conference on Soft Computing MENDEL. Brno, ČR, 2019.

OSMERA SENIOR, Pavel, Daniel ZUTH, Anna KUCEROVA, Pavel OSMERA JUNIOR, Monika DOSOUDILOVA, Jan MULLER, Tomas MARADA a Ladislav DOBROVSKY. Ring models of atoms, molecules and nanomaterials. Advanced Materials Letters. Švédsko, 2019.

OSMERA SENIOR, Pavel, Daniel ZUTH, Anna KUCEROVA, Pavel OSMERA JUNIOR, Monika DOSOUDILOVA a Jan MULLER. GRAMMATICAL EVOLUTION FOR DESIGN OF NANOSTRUCTURE MODELS. International Conference on Soft Computing MENDEL. Brno, ČR, 2018.

\section{Patents}

MÜLLER, Jan a Rudolf MÜLLER. Zařizení pro kontinuální a definovanou změnu geometrie tvaru a zakřivení profilu kř́del. ČR. Patent 300 728. Uděleno 29.07.2009.

MÜLLER, Jan. Systém zabezpečení přemistitelných předmètů fixací jejich polohy. ČR. Patent 297 511. Uděleno 03.01.2007.

MÜLLER, Jan a Rudolf MÜLLER. Vicekomorová dvoupláštová kubická nádrž. ČR. Patent 296 976. Uděleno 16.08.2006.

MÜLLER, Jan a Rudolf MÜLLER. Vicestupňový absorpční separátor. ČR. Patent 299 890. Uděleno 29.12.2008. 